\title{
実大試験壁体における熱湿気同時移動モデルの検証 VERIFICATION OF THE SIMULTANEOUS HEAT AND MOISTURE TRANSFER MODEL USING FULL-SCALE TEST WALLS
}

\author{
坂本雄三*, 渡辺一正** \\ Yuzo SAKAMOTO and Kazumasa WATANABE
}

\begin{abstract}
The authors verified the simultaneous heat and moisture transfer model using six different full-scale test walls in which hygroscopic materials were used. Humidity. water content and temperature inside the walls were measured for about one year in the field test. Principal physical properties of used materials were measured independently in other experiment rooms. One-dimensional numerical calculations corresponding to the test were performed by applying the measured physical properties and the observed boundary conditions. Agreement between the calculation and the measurement is fairly good except for materials composed of cement, such as aerated concrete. Validity and subjects on the model were suggested.
\end{abstract}

Keymords:sidultaneous heat and moisture transfer, numerical calculation, verification, internal condensation, hygroscopic materials. 熱湿気同時移動, 数值計算, 険証, 内部結露, 吸放湿性材料

1.はじめに

建築壁体における水分移動の解析モデルを確立するこ とは壁体内外の結露や室内湿度・潜熱負荷を予測する上 で極めて重要な研究テーマの一つである。我国において は松本ら"12)，3，4によって主にAＬＣを対象として吸 放湿性材料中の水分移動のモデルが研究されてきた。こ の水分移動のモデルは熱移動のモデルと一体となってい るので、熱湿気同時移動モデルと呼ばれており、計算値 と実験值の比較によるモデルの検証む試みられている。 これらの検証結果によると、ヒステリシスまで含めて材 料物性值が正確に与えられていれば、このモデルはかな りの精度で壁体中の水分挙動を予测できることが示され ている2)、か。たがって、このモデルは基本的には妥当 と考えられ、実用的にす有望なモデルであるとの定評が ほぼ確立されている。しかしながら、動的熱真荷計算な どとは違って、熱湿気同時移動モデルによる予测計算は 実際の建築設計業務において一般化しているわけではな
い。この理由としては実際の設計業務においてこのよう な計算を行う必要がそれほど生じないということも考え られるが、このモデルにおいて用いられる水分伝導率や 平衡含水率等の物性データが十分に整備されていないと いうことが最大の理由と思われる。

ところで、このような物性データの不備を除いたとし ても、このモデルを実際の壁体設計に活用することに関 してはまだいくつかの問題が残っている。なぜならば、 計算值と実測值の比較検証が試みられているといっても、 実験室における小規模な実験において単一の材料（主に A L Cであり、様々な材料について行われているわけで はない）について検証されたものがほとんどであり、様 々な材料が層状に重ねられている実際の建築壁体につい て実際の使用状態の下で検証されたものは皆無に近いか らである。このような状況を踏まえ、このそデルの実用 化にあたってさらに検討を加えるべき事項を次のように 整理した。
* 名古屋大学工学部建築学科 助教授. 工博

** 建設省建築研究所第五研究部 防火研究調整官 · 工修
Assoc. Prof., Dept. of Architecture, Faculty of Eng., Nagoya Univ., Dr. Eng.

Vice-director, Environment, Design and Fire Dept., Building Research Institute, Ministry of Construction, M. Eng. 
1) 壁体の一般部分を解析するときは熱負荷計算では 1 次元問題として扱う場合が多いが、非定常の熱湿気同時 移動計算においてもこの仮定が許されると判断してょい か。室内の垂直温度分布や軸組部材の影響は通常大きく ないと見なして問題はないか。

2 ）複数の板状部材を用いて通常の施工精度の下で製作 された壁体においてす、モデルで設定されるようなシン プルな境界条件がほぼ成立していると考えて大きな問題 は生じないか。例えば、部材と部材との間に生じるごく 小さな隙間が大きな影響を及ぼすことはないか。

3）実際に使用される建築材料においては、たとえ同じ ような方法で製造されている材料であってあ物性值まで 完全に等しいとは限らない。なぜならば、湿気に関する 物性值は材料組織の微細な構造に強く依存するので、製 造過程における何らかのバラッキが物性值に影響を及ぼ したり、一枚の製品の中です異方性や非一様性が少なか らず存在している可能性がある。また、緩慢な化学反応 による長期的な変化る考えられる。実用計算においてこ のよう物性值のバラッキ、非一様性、長期変化といった あのは無視できるのか否か。

4) 建設後初期の結露予測においては材料の初期含水率 が大きな影響力を持つと考えられるが、実際の設計業務 においてこのような初期結露の予測を行おうとする場合、 初期含水率はどのようにして与えたらよいのであろうか。 測定して初期含水率を与えるということは実際の設計業 務に扔いては非現実的之思われる。それ故、初期含水率 に関する何らかの指針や妥当な推定方法が示されなけれ ば、事実上このような予測は不可能になってしまう。 本研究は、熱湿気同時移動モデルの実用化に当たって はこのような疑問や問題が存在するということを念頭に おきつつ、多層の材料で構成される実大の建築壁体を試 験体にして松本らが定式化しているモデルによる計算結 果と試験における测定結果とを比較するすのである。こ のような比較によって上記の疑問や問題がすべて明快に 解決されるとは考えられないが、それぞれの重要性等に 関して何らかの示唆が得られるものと期待され、そのよ うな示唆を得ることが本研究の大きな目的である。つま り、実大の壁体において熱湿気同時移動モデルの予測精 度を検証・吟味し、モデルの全般的な妥当性を評価する とともに、モデルを使用した予測計算の実用化にあたっ てポイントになる事項や注意すべき事項を鲜明にしよう とするあのである。

なお、このような熱湿気同時移動モデルを用いた沈用 計算においては異なる時間スケールを持つ二つの典型的 な砈用例が考えられる。第一の伈用例は吸放湿性に富む 壁体における内部結露の検討のような例である。この場 合は温湿度の季節変動が重要な条件になるので、対象と すべき期間は 1 年〜数年という長期間になる反面、数日
程度以下の短周期の变動などはほとんど影響がなくなる。 むう一つの応用例は間欠空調における潜熱負荷計算のよ うな例である。この場合は 1 時間以下の速い温湿度変動 が存在する条件の下で計算しなければならないので、扱 う現象の時間スケールは第一の応用例に比べて非常に短 くなる。本研究では問題が極度に複雑になるのを避ける ため、このような時間スケールに関しては前者（季節変 動的時間スケール）に着目し、後者のような短時間スケ ールのあのは当面は対象としない方針で研究を進めた。 したがって、本稿において検証結果として示される温湿 度等のデータは全て日平均値に関するむのであることを 予め言及しておく。

\section{2. 実大試験の方法}

\section{（1）試験壁体}

実大試験は大断面の集成材を柱・梁に用いた多目的実

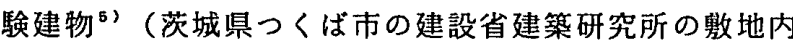
に建設）の北側の一室を使用して行われた。図 1 に示す ように、この実験建物の北側の直達日射が当たらない外 周部に Aから $\mathrm{F}$ までの 6 体の試験壁体を設置した。これ らの試験壁体はいずれも同じ大きさであり、1体のサイ ズは $1030 \mathrm{~mm}$ (横) $\times 2640 \mathrm{~mm}$ (高さ) $\times 252 \mathrm{~mm}$ (厚さ)であ る。これらの試験壁体の層構成と材料を図 2 に示すが、 以下のような検討を踏まえてこのような壁体仕様が決定 された。

熱湿気同時移動モデルを用いる非定常計算は吸放湿性 に富む壁体の湿気挙動を予測するために行われるのであ るから、そのような特性を有する壁体が多く試験されね ばならない。しかし、一方では、比較のために現在一般 的に造られているあまり吸放湿性に富まない壁体も必要 と考えられる。また、コンクリートは非常に一般的な建 築材料ではあるが、壁体中の湿度や含水率を測定する際

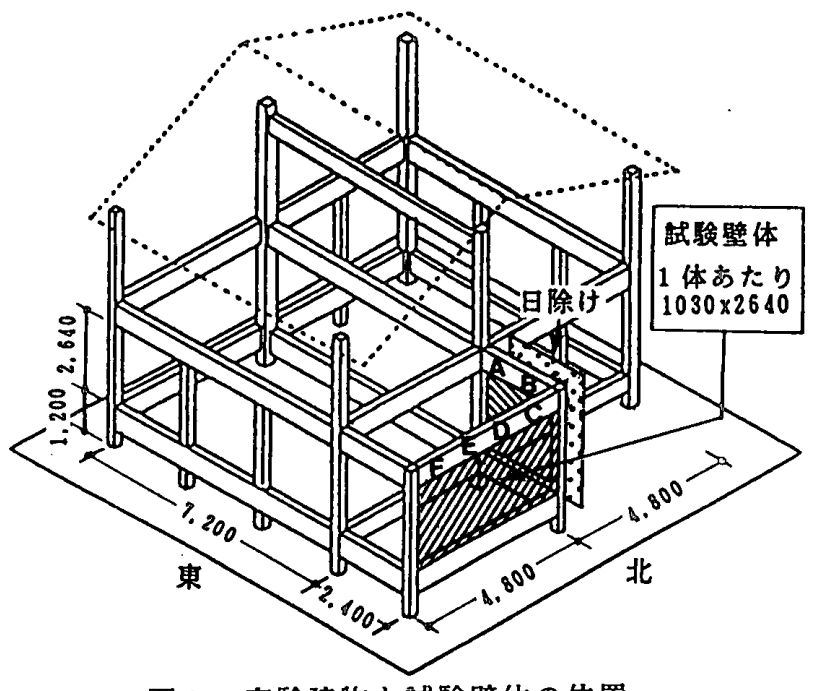

図 1 実験建物と試験壁体の位置 
には厄介な問題が予想される。このような諸々の事情を 勘案した結果、現在の一般的な仕様のもの（吸放湿性に は富んでいない）が 2 体、吸放湿性に富む新規的なもの が 4 体、製作されることになった。即ち、A壁体とB 壁 体はわが国の木造軸組建築において一般的な仕様と考え られるすのであり、Aは防湿層が撖重に施工されたもの、 $\mathrm{B}$ は防湿層が粗雑に（防湿クラフト紙に小孔がいくつか 人為的にあけられている）施工され且つ外気側に防水層 が設けられたものである。C〜 F の壁体はいずれも吸放 湿性に富む材料がふんだんに用いられた壁体であり、本 試験において熱湿気同時移動モデルを重点的に検証する 目的も兼和て製作された。各壁体は熱抵抗の違いによる 熱性能上の差異をできるだけ小さくするために、熱貫流 率がほぼ同一の值になるようにグラスウールの厚みが調 整されている。各壁体に内装材として使われた石膏ボ一 ドの外気側にはいずれむかなり厚い空気層があるが、こ れらは本実験建物で用いられている大断面の柱・梁表面 と内装材表面を一致させるために生じた空気層であり、 特別に意図されたものではない。一方、外装材の室内側 にある通気層（B壁体だけは密閉空気層だが）は壁体内 部を通過してくる湿気を外気にスムーズに排出させるこ とを目的として設けられた。

試験壁体の製作の際、材料の品質や製作精度について は特段注意を払わなかった。ごく一般の建筑物の施工と 同様に現場施工でそれらを製作・設置した。これは本研 究が熱湿気同時移動モデルを実用化する際に発生すると 思われる問題点等を探ることを目的としているためであ り、一般の建築とは異なる施工を意図的に行うことは逆 にこのような問題点を不明瞭にすると考えたからである。 また、次節で詳述するが、試験壁体に用いられた主な材 料についてはそれらのサンプルを用いた物性測定が別途 実験室において行われた。

（2）测定方法と試験方法

試験壁体内部における熱湿気の状態を測定するために、 各試験壁体の内部には図 2 に示すように、温度センサー （C－C 熱電対）と相対湿度センサー（ヴァイサラ社の 高分子絶縁膜系センサー）を数個ずっ埋め込んだ。同様 なセンサーは室内と外気の温湿度測定にも使用した。ま

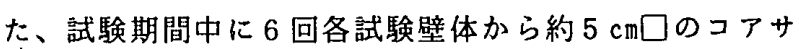
ンプルを取り出し、その重量分布を電子天秤で測定する 方法によって含水率分布を求めた。

試験壁体が設置されている室内は市販のエアコンと加 湿器（暖房時のみ使用）を用いて表 1 に示すような条件 で冷房或いは暖房を行った。冷房温度が $20 〜 26^{\circ} \mathrm{C}$ とやや 低めに設定されたが、これは住宅ばかりでなく商業建築 も考虑して冷房温度を想定したからである。温湿度の測 定はどの測定点も 1 時間間隔で行われ、測定結果はデー タロガーに収録された。試験は1989年7月22日から1990

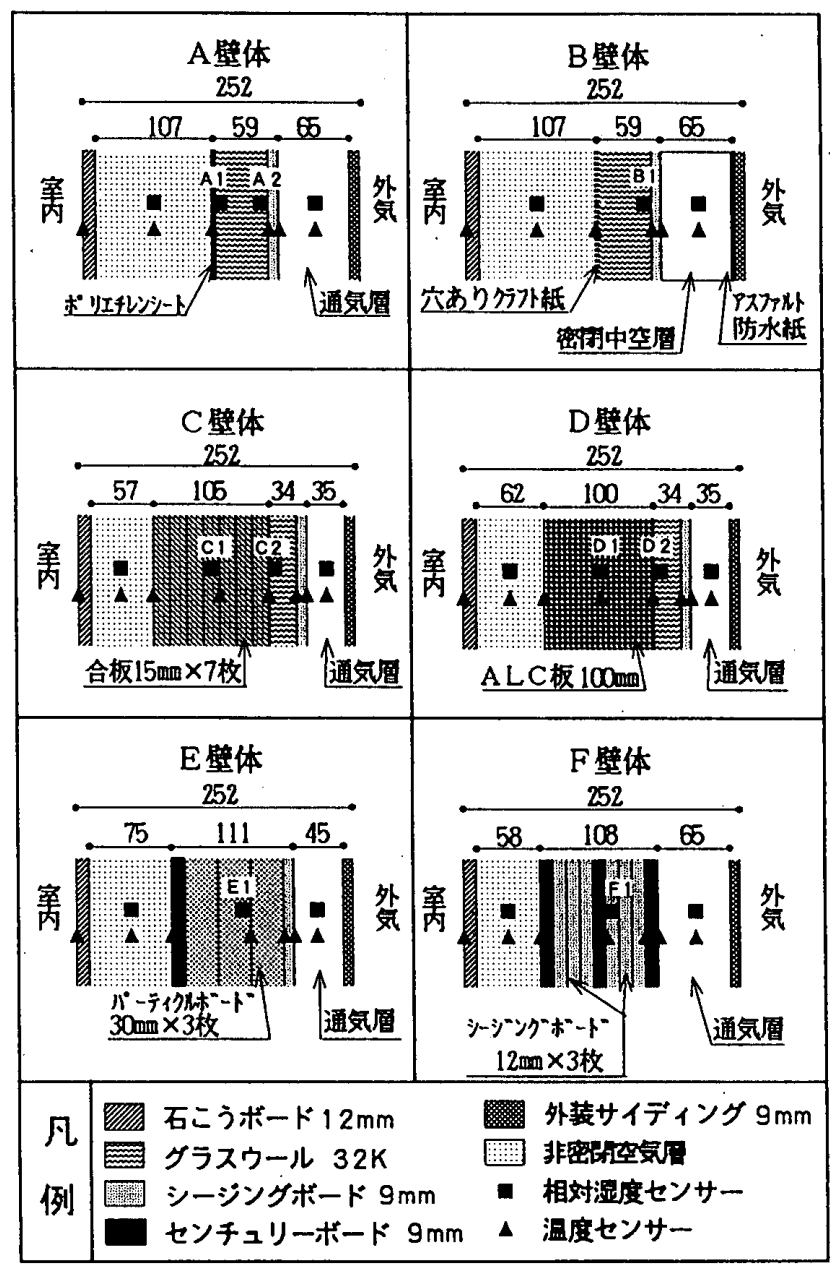

図 2 試験壁体の層構成と温湿度の测定点

表 1 空調の設定条件

\begin{tabular}{|l|c|c|}
\hline \multicolumn{1}{|c|}{ 項 目 } & 冷 房 & 暖 房 \\
\hline 設定温度 & $20 \sim 26^{\circ} \mathrm{C}$ & $22^{\circ} \mathrm{C}$ 上 \\
設定湿度 & なりゆき & $40 \%$ 以上 \\
日運転時間 & 8時〜20時 & 8 時〜20時 \\
空調期間 & 7月 22日〜9月5日 & 12月1日〜4月1日 \\
\hline
\end{tabular}

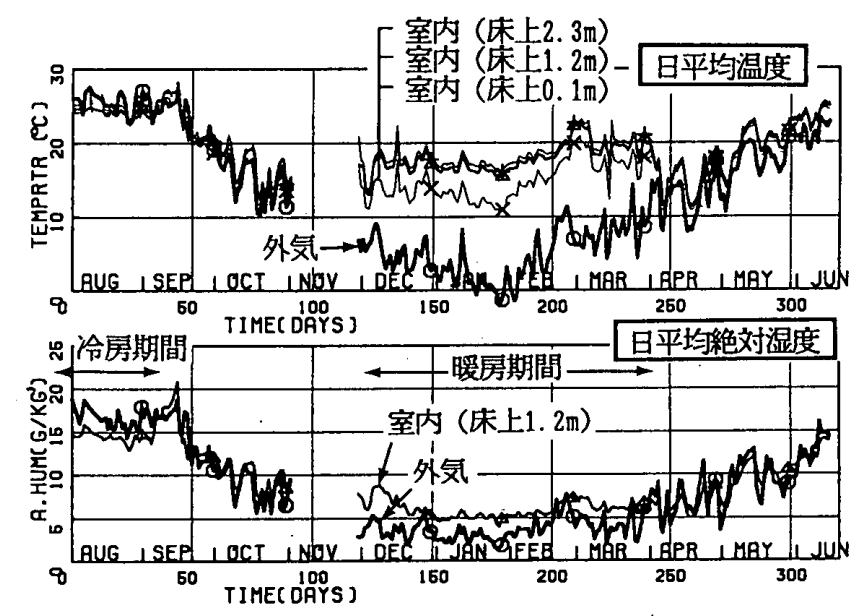

図 3 室内および外気の日平均温度と日平均絶対湿度 
年 6 月15日まで行われたが、途中11月に本試験とは直接 関係のない工事のために約1 カ月ほど測定を中断せさる をえない期間があった。図 3 に試験期間中の室内と外気 の日平均温度及び日平均絶対湿度の測定結累を示す。室 内温度に関しては床上からの高さが異なる3点の測定結 果が示されており、上下温度分布の様相を読みとること ができる。つまり、室内の上下温度差は暖房期間では2 $5^{\circ} \mathrm{C}$ 程度あるが、それ以外の期間ではほとんどないことが 分かる。また、室内外の絶対湿度を比べることにより冷 房期の除湿と暖房期の加湿の程度を把握することすでき る。

\section{3、計算モデルと計算方法}

（1）基碄方程式

本研究で使用した熱湿気同時移動モデルの基樥方程式 (は松本4)によって定式化されている化学ポテンシャルを 水分移動ポテンシャルとするすのであり、外力が存在し ない1次元系では次式で示される（記号の意味について は表 2 に示す)。

$\rho_{w} \frac{\partial \phi}{\partial \mu} \frac{\partial \mu}{\partial t}=\frac{\partial}{\partial x}\left(\lambda_{\mu}^{\prime} \frac{\partial \mu}{\partial x}+\lambda_{T}, \frac{\partial T}{\partial x}\right)$

$c \rho \frac{\partial T}{\partial t}=\frac{\partial}{\partial x}\left\{\left(\lambda+r \lambda_{T G}^{\prime}\right) \frac{\partial T}{\partial x}+r \lambda_{\mu G}^{\prime} \frac{\partial \mu}{\partial x}\right\}$

（1）式は水分の収支を、（2）式は熱エネルギーの収支を表 している。また、 $\lambda$ '等の伝荨率には以下の関係がある。

$$
\begin{aligned}
& \lambda_{\mu}^{\prime}=\lambda_{\mu G}^{\prime}+\frac{h}{R_{V} T} \frac{\partial \phi}{\partial h} D_{\phi L} \\
& \lambda_{r}^{\prime}=\lambda_{T G}^{\prime}+D_{r L} \\
& \lambda_{\mu G}^{\prime}=\frac{P_{v S} h}{R_{V} T} \lambda^{\prime} \\
& \lambda_{T G}^{\prime}=\frac{d P_{v S}}{d T} h \lambda^{\prime}
\end{aligned}
$$

以上から分かるように、材料固有の数值である 6 種穎の 物性值 $\left(\phi, \lambda^{\prime}, D_{\phi L}, D_{T L}, \lambda, c \rho\right)$ が与えられてい 九ば、適切な境界条件の下で(1)式と(2)式を連立させて $\mu と T$ を数值的に解くことが可能である。

（2）材耀物性值の設定

本研究では各壁体に使用されている材料の吸放湿性に 閣わる物性值についてはできるだけ独自に測定したもの を用いることにした。即ち、主要材㪴の $\phi, \lambda ’, \rho に$ ついては別途実験室において独自に测定した。ただし、 一般に存在が認められている 対湿度依存性については、計算結果に与える影響が小さ いるのと考え考剭しなかった。

本研究で測定された重量平衡含水率 $\left(=\phi \rho_{W} / \rho\right)$ の 吸湿曲線と放湿曲線を図 4 に示す。ただし、A L C の相
対湿度 $98 \%$ 以上に対する含水率だけは既存の文献 ${ }^{4}$ 等を 参考にして想定した。吸湿曲線は絶乾状態から、放湿曲 線は相対湿度 $98 \%$ から湘定したものである。センチュリ 一ボードとAＬＣにかなり強いヒステリシスが見られる。 後に詳述するが、本試験ではA L C のみが初期含水率が 非常に高く試験期間中はほとんど放湿状態であったと想 像さ机る。しかし、AＬＣ以外の材料については、グラ スウールの場合は結露が発生したがヒステリシスがほと んどないので、また、それ以外の材料では試験期間中相

\begin{tabular}{|c|c|c|c|}
\hline 記号 & 意 哧 & 記乓 & 意 哧 \\
\hline \multirow{5}{*}{$\begin{array}{l}c \\
D \\
h \\
P_{\mathrm{vs}} \\
R_{\mathrm{v}} \\
r\end{array}$} & \multirow{6}{*}{$\begin{array}{l}\text { 材料の比熱 } \\
\text { 材㩽の水分伝導率 } \\
\text { 相対湿度 } \\
\text { 飽和水蒸気圧 } \\
\text { 水蒸気の気体定数 } \\
\text { 気相から液相への } \\
\text { 水の相変化熱 } \\
\text { 䇶䇃泹度 }\end{array}$} & $\mu$ & 水分の化学が テッッャカ \\
\hline & & $\rho$ & 材料の密度 \\
\hline & & $\rho_{\text {v }}$ & 液水の密度 \\
\hline & & $\phi$ & 材料の体積含水率 \\
\hline & & 添字 & 意 粴 \\
\hline$T$ & & G & 気水成分 \\
\hline$t$ & 時間 & $\mathrm{L}$ & 液水成分 \\
\hline$x$ & 距離 & $\mathrm{T}$ & 温度勾配 \\
\hline$\lambda$ & 材料の熱伝導率 & $\mu$ & 化学末゚テソシャ时勾配 \\
\hline$\lambda^{\prime}$ & 材科の水分伝蓪率 & $\phi$ & 含水率勾配 \\
\hline
\end{tabular}
対湿度が大方 $90 \%$ 以下であったので、ヒステリシスによ る平衡含水率の差異は考虑しなくてもよいるのと思われ

表 2 数式に用いられている記号の意㙅
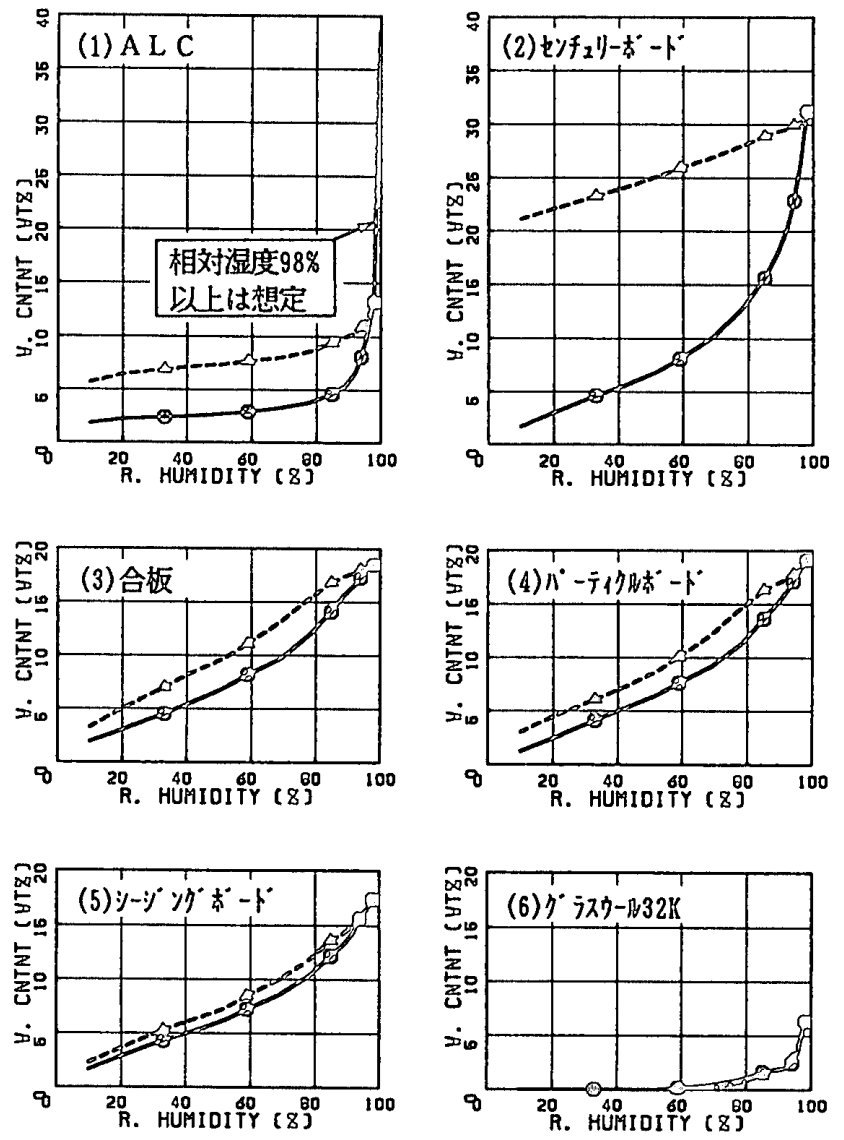

図4主な使用材紏の重呈平衍含水率 (一吸湿過程, ……放湿過程) 
る。それ故、計算用の平衡含水率としては、A L C に対 しては放湿曲線を、その他の材料に対しては吸湿曲線を 適用した。同様な理由を水分伝導率にむあてはめ、A L $C$ に対しては液水成分の伝導率である $D_{\phi L}$ と $D_{T L}$ を無視 できないが、それ以外の材料においては主に水蒸気拡散 によって水分移動が行われるために $D_{\phi L}$ とD $D_{T L}$ は無視で きるあの!とした。したがって、AＬCに対してのみ、

$2.5 \% \leqq \phi \leqq 20 \% の$ 範囲で、

$D_{\phi L}=1.15 \times 10^{-2}(\phi-0.025) \quad[\mathrm{kg} / \mathrm{mh}]$

$D_{T L}=4.32 \times 10^{-4}(\phi-0.025) \quad[\mathrm{kg} / \mathrm{mhK}]$

という既存の測定データ か) から得られる近似式が適用さ れた。ただし、これらの温度依存性については影響が小 さいすのとして無視した。

$\lambda$ 'についてはカップ法（二つのカップの相対湿度は $50 \%$ と $85 \%$ 、温度は $20^{\circ} \mathrm{C}$ ) を用いて、また、。について は容積と重量を測定して湘定值を得た。これ以外の物性 值やシート類の入'に関しては既存の文献”，8)に揭載さ れている数值を引用した。これら計算で用いられた物性 值をまとめて表 3 に示す。また、熱伝導率の含水率依存 性についてはすべての材料で無視した。

\section{（3）境界条件と初期条件}

本試験においては各壁体の両側に位置する空気層にお いて 1 時間毎に温湿度が測定されたので、それらのデー 夕を境界条件として計算を行った。室内及び外気の温湿
度を境界条件として計算することも可能であるが、その 場合には空気層における通気量をどのように与えるかが 大きな問題となる（特に外気側の空気層は通気層になっ ている）。しかし、このような通気量の設定方法に関す る影響が混入すると、却って着目している因果関係が不 明瞭になる危険性す生じる。このような䝮念から、本研 究ではまずは上記のように空気層の温湿度を境界条件と

表 3 計算で使用した主な物性值

\begin{tabular}{|c|c|c|c|c|c|c|c|c|}
\hline & \multicolumn{2}{|c|}{ 䋓乾 } & \multicolumn{2}{|c|}{ 熱伝導率 } & \multicolumn{2}{|c|}{ 比熱 } & \multicolumn{2}{|l|}{ 湿気伝導率 } \\
\hline & $\begin{array}{l}\mathrm{kg} \\
/ \mathrm{m}^{\mathrm{s}}\end{array}$ & $\#$ & $\begin{array}{l}h^{\circ} \mathrm{C} \\
{ }^{\circ}\end{array}$ & $\#$ & $\begin{array}{r}\mathrm{kcal} \\
\mathrm{kg}^{\circ} \mathrm{C} \\
\end{array}$ & & $\mathrm{g} / \mathrm{mh}$ & \\
\hline A L C & 19 & A & 13 & & 0.26 & $B$ & 0.0 & \\
\hline 1 & 892 & A & 0.19 & & 0.40 & D & 0. & \\
\hline & 644 & A & 0.16 & & 0.31 & b & 0.0040 & \\
\hline $2 n$ & 416 & A & 0.15 & D & 0.31 & B & 0.0 & \\
\hline * & 322 & A & 0.052 & B & 0.31 & B & 0.0 & \\
\hline 坊-N3 & 32 & A & 0.031 & B & 0.20 & B & 0.1 & \\
\hline エチレンシート & 700 & c & $0: 1$ & C & 0.31 & C & 0.0 & \\
\hline ありクラフト各 & 00 & & 0.18 & & 0.31 & & 0.03 & \\
\hline
\end{tabular}

[\#欄の意味]

$A$ : 自主測定值（湿気伝導率は $20^{\circ} \mathrm{C}$, 相対湿度50〜85\%で測定） B:建築学便覧" から引用
C: 同 の「防湿紙類」を適用
D：同 の「硬質木片七以㤆」を適用
$\mathrm{E}$ ：同 の「ろ紙」を適用

$\mathrm{F}:$ 土屋喬雄 ${ }^{()}$'の提案值
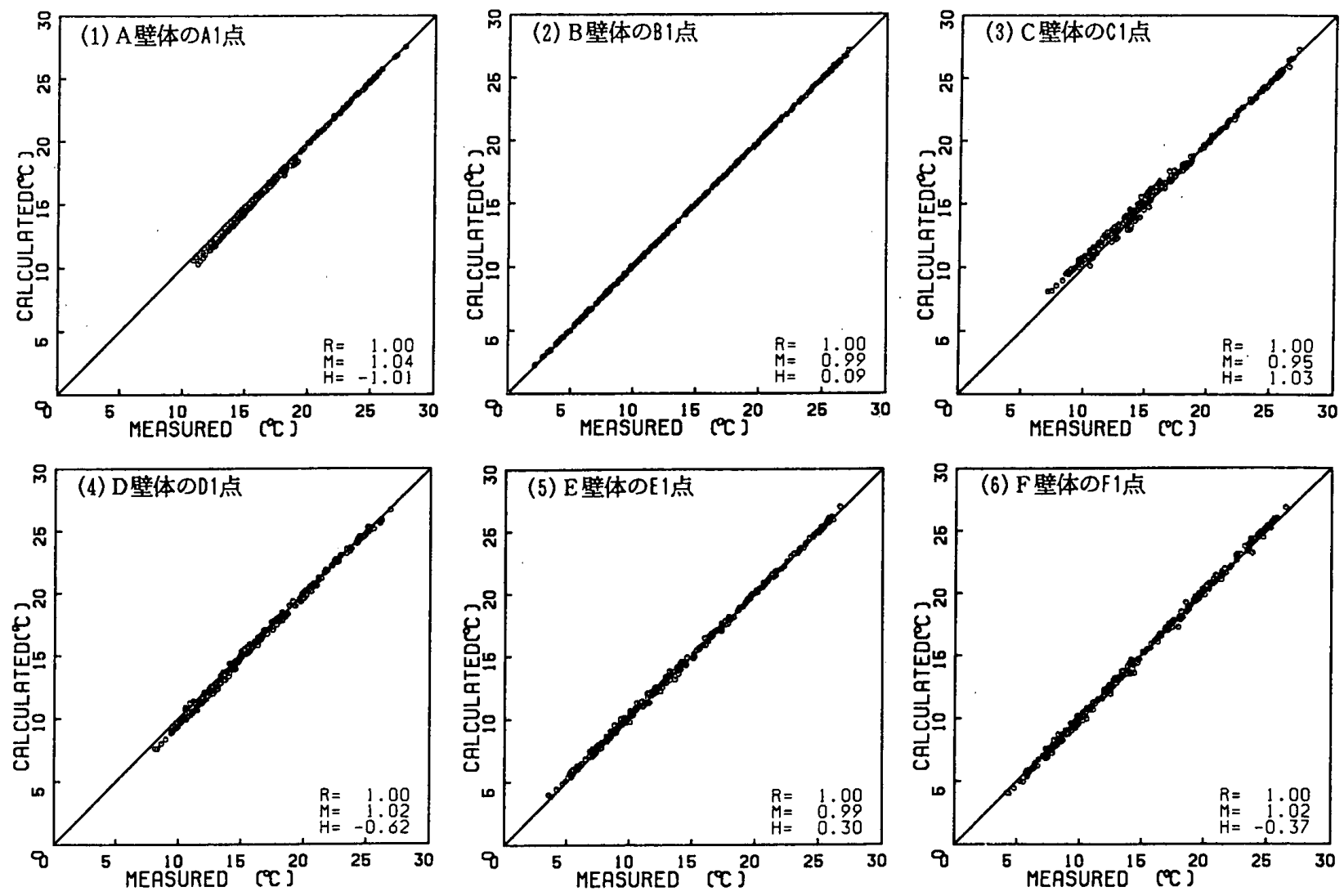

図 5 各壁体内部の日平均温度に関する計算值（縦軸）と测定值（横軸）の比較 
する計算だけを行うことにした。なお、先述した测定の 中断期間においては、境界条件は中断前後の日平均值と 日変動とを考虑した仮の温湿度を与えざるをえなかった。 また、空気層と材料表面との間の伝達率については、一 定の総合熱伝達率 $\left(=9.3 \mathrm{~W} / \mathrm{m}^{2}{ }^{\circ} \mathrm{C}\right)$ 、亚びに、対流熱伝達率 $\left(=4.65 \mathrm{~W} / \mathrm{m}^{2}{ }^{\circ} \mathrm{C}\right.$ で一定)とルイスの関係式より得られる水分 伝達率")を与えた。

初期条件は1989年8月2日の各壁体内部の温湿度湘定值 と含水率測定值を参考にして設定し、同日の0時を計算開 始時点とした。

(4) 数值計算の方法

熱湿気同時移動モデルに基づく数值計算は（1)式と(2) 式を時間後退差分と空間中心差分で近似し、緩和法で $\mu$ とTの分布を同時に求める方法で行った。壁体の分割幅 については誤差をできるだけ避けるために空気層に接す る表面近くでは $1 \mathrm{~mm}$ 以下に細かく分割した。その結果、各 壁体の分割格子数は $\mathrm{A}$ 壁体と $\mathrm{B}$ 壁体で16個、その他の壁 体では34〜44個になった。このような空間分割の下で時 間の增分間隔を 1 時間とし、各壁体に対して試験期間に 対応するはぼ 1 年分の計算を行った。

\section{4. 㖕算值と測定值との比較及ひ考察}

\section{(1) 温度と湿度に関する比較と考察}

図 5 は各壁体内部の温度測定点における日平均温度を 計算值と测定值について比較した例である。両者はいず れも非常に良く一致しており、熱伝導率の設定值には大 きな問題がなかったことが分かる。

図 6 は壁体内部の相対湿度測定点における日平均相対 湿度について計算值と测定值を時系列で比較したもので ある。図 7 は同様なデータを絶対湿度に換算し、計算值 と測定值の対応を見たものである。相対湿度の比較にお いては D壁体における一致が悪く、両者の差は D 1 点に おいて最高20\%程度である。この差には D 壁体の含水率 が非常に高い（図 8 参照）ために生じた湿度センサーの 誤差（センサーの精度は相対湿度95\%以下でしか保証さ れていない）す含まれているすのと思われる。その他の 壁体では部分的に一致が悪いところる散見されるが、変 動の様相等はほぼ一致しており、全般的にはかなり良く 一致していると結論づけることができる。絶対湿度にお いて比較すると、このような一致の状況は一層強く示さ れる。

（2）含水率に関する比較と考察

図 8 は試験期間中各壁体において 6 回測定された重里 含水率分布とその测定日における計算值の日平均とを比 較したすのである。湘定值を示す棒グラフにおいて各棒 の幅は重量を测定したサンプル片の厚さを示している。 計算の開始時点となった1989年8月2日における比較は除

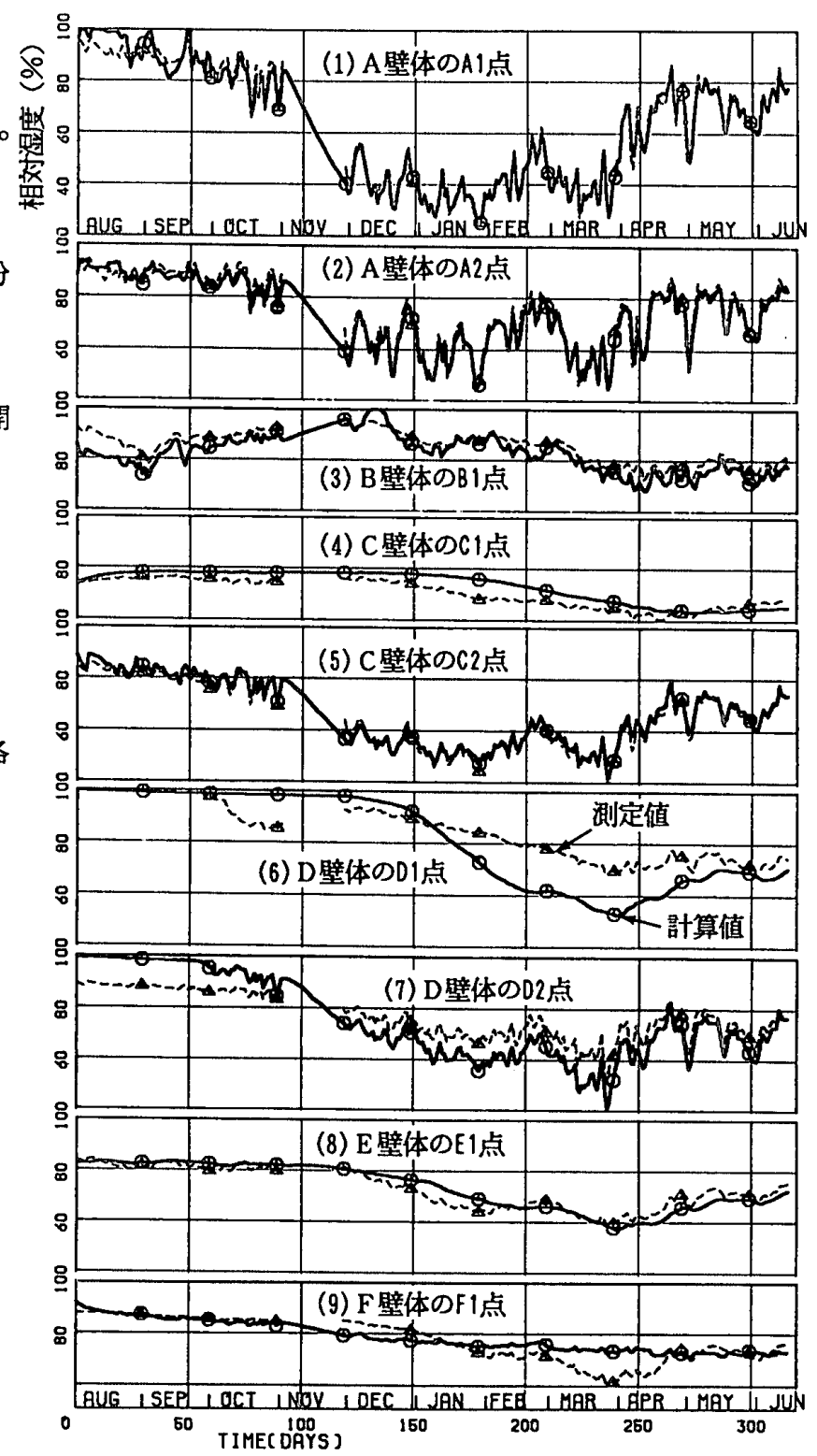

図 6 各壁体内部の日平均相対湿度に関する 計算值 (一) と湘定值 $(\cdots \cdot-\cdot)$ の比較

くことにして、以下にこのような比較から考察できるこ とを壁体別に示す。

1) $\mathrm{A}$ 壁体：計算では夏期にグラスゥールの室内側で部 分的に結簬し高含水率になっているが、測定ではグラス ウールのサンプル片を薄くできなかったことああってこ のような結露を確認できずに終わっている。それ以外は 計算值と測定值との間に際だった差異はない。

2) B 壁体: 測定では1990年 1月11日にグラスゥール内 の結露による高含水率が見られるが、計算ではそれが発 生していない。1 次元の計算モデルでは防湿層にあけた 小孔の効果を適切に表現できないことが原因と思われる。 これ以外についてはA壁体と同様に両者に大きな差異は 見られない。

3）C壁体：計算值と测定值との間には全般的に大きな 差は見られない。しかし、この壁体は図6の(4)と（5)に 
示したように、試験期間中、相対湿度はそれほど高くは ならなかった（約 $90 \%$ 以下）。したがって、計算值と測 定値との差が小さいといっても、それは高湿度にならな い条件のもとで確認された事実であることを明記しなけ ればならない。結露を生じるような高湿度の条件におい てあ計算值と测定值がこのように一致するかどうかは本 試験だけでは断定できない。

4） D壁体：既述したようにA L C の初期含水率が異常 に高い。これは製造されてから比較的日の浅いA L C を 用いたからである。計算では A L C は测定より数力月早 く乾燥するという結果になっている。にすかかわらず、 乾燥後の含水率については計算值の方がやや高い值を示 している。このような不一致の原因としては、AＬＣの
物性値における食い違いが最も高い可能性を持っている。 この食い違いには二種類考えられ、一つは物性值の測定 誤差が原因で生じる食い違いであるが、あう一つは計算 における物性值の扱い方が適切でないために生じる食い 違いである。後者をすう少し具体的にいうと、本計算に おいては $98 \%$ とう不十分な相対湿度から放湿を開始し だ平衡含水率（図 4 (1)参照）を適用したり、 $D_{\phi L}$ と

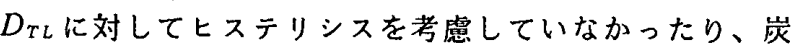
酸化などの化学反応によって発生する微細構造の変化 ${ }^{\text {) }}$ が原因となる物性値の変化を無視しているが、このよう な物性值に対する扱い万や仮定が不一致の原因になって はいないかということである。しかし、原因の可能性が あるこれらの中から真の原因を特定するためには、物性
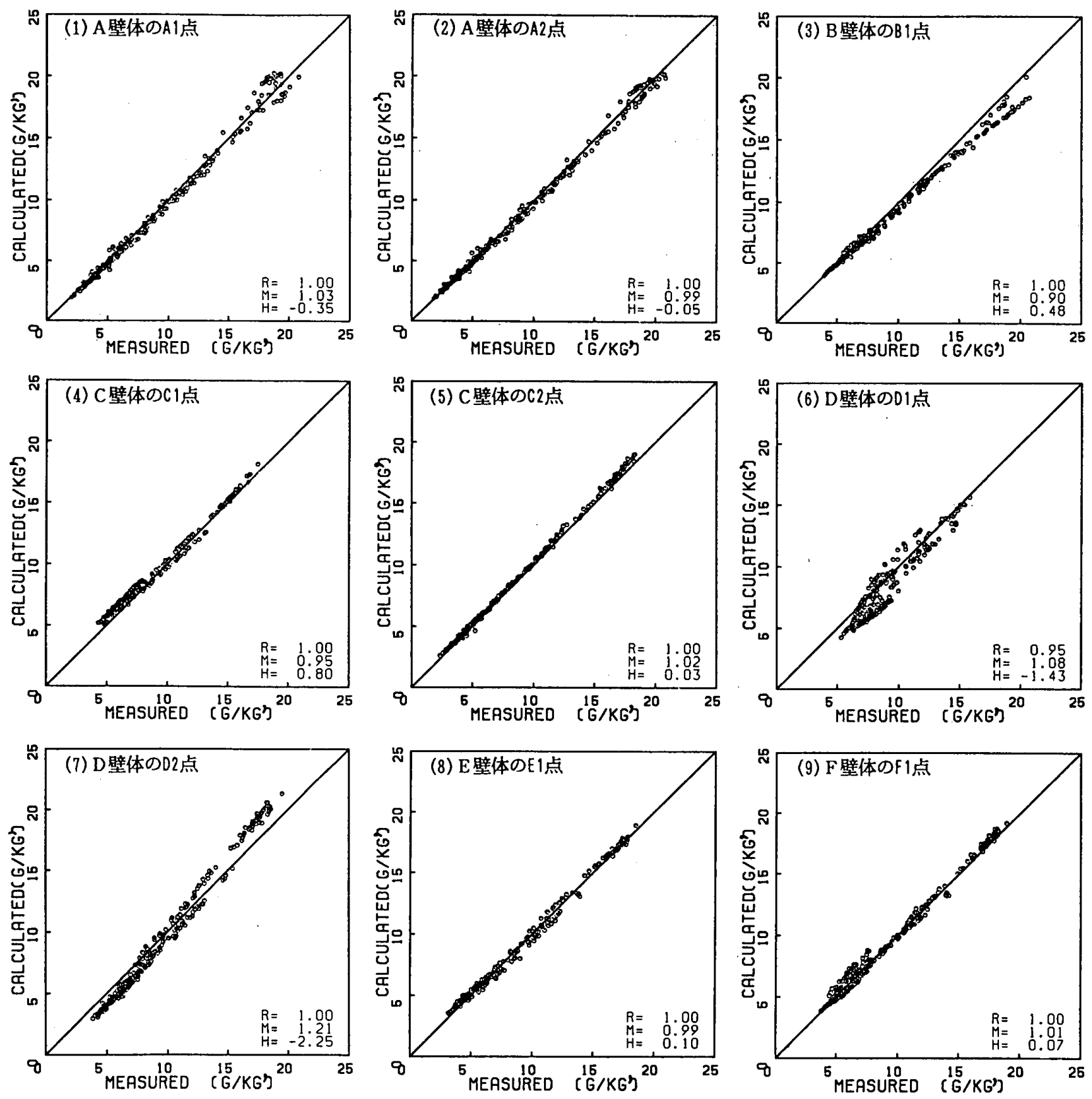

図 7 各壁体内部の日平均絶対湿度に関する計算値（綎軸）と测定値（横軸）の比較 
値に関する再測定や物性值に対する様 々な感度解析などがさらに必要である。 したがって、本論文では予想される原 因を列挙するだけにとどめ、本格的な 究明については次の課題として続報で 検討することにしたい。

5) E壁体：センチュリーボードの計 算値が測定値より全般的にかなり高い。 それ以外は雨者に大きな差異は見られ ないが、C壁体と同様に試験期間中の 相対湿度は $90 \%$ 以下であり、高湿度状 態には一度もなっていないので、この ような結果が高湿度条件まで当てはま るかどうかは断定できない。

6) $\mathrm{F}$ 壁体： $\mathrm{E}$ 壁体と同様にセンチュ リーボードの計算值が全般的にかなり 高い。シージングボードに関しては両 者は比較的よく一致しているが、C壁 体や $\mathrm{E}$ 壁体之同様に高湿度にはならな い条件における結果であることには留 意しなければならない。センチュリー ボードにおけるこのような不一致に関 しては、センチュリーボードにはセメ ント系の物質が含まれていることから

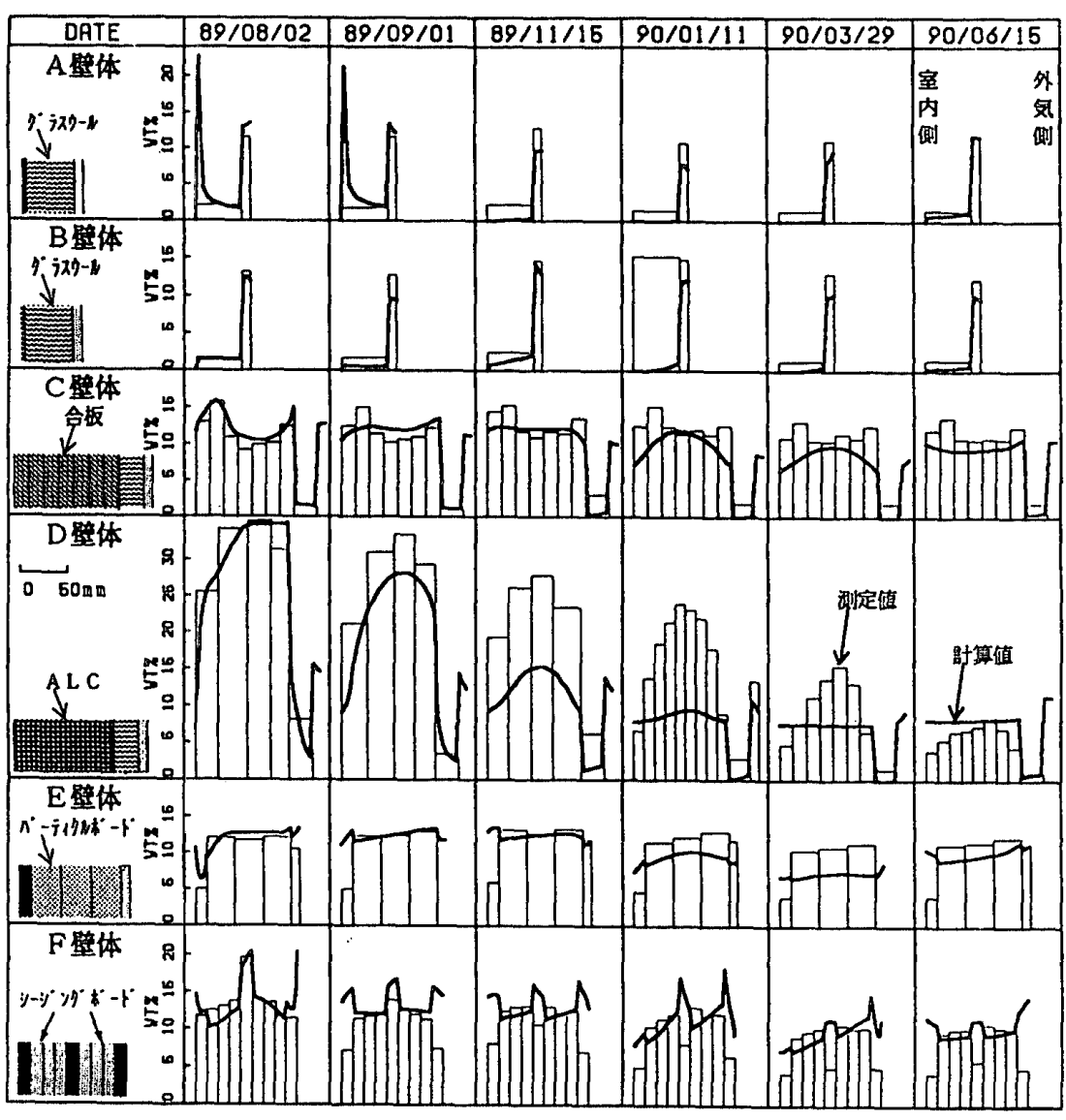

図 8 各試験壁体における重量含水率の計算值（太線）と剆定值（棒グラフ） 推定して、D壁体のA L C の場合と同

様ような原因が考えられる。したがって、これについて あ続報で検討することにしたい。

\section{5.むすひ}

6 種穎の実大の試験壁体において 1 次元の熱湿気同時 移動モデルを用いて計算される温湿度や含水率の計算結 果と測定結果を日平均值で比較し、このモデルの有効性 と実用性を検証した。このような比較・検証から得られ る知見を冒頭に示した四っの検討事項に対応させて以下 に示す。

1) 1 次元計算の妥当性について

本計算が 1 次元計算であるが故に生じたと思われる計 算値と湘定值の不一致は、B 壁体の小孔が原因と思われ る結露だけであった。冬期には室内にかなりの上下温度 差が発生していたが、それが原因と思われる不一致は今 回の計算では発見できなかった。尚、1 次元計算の妥当 性を厳密に検証するのであれば、本試験のような湘定で は不十分であり、壁面全体を対象としたより精緻な測定 が必要と考えられる。

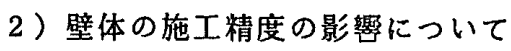

本試験壁体のようにごく普通の施工精度ですって製作 された壁体においても、部材と部材の隙間などが影暨し

ていると思われる測定結果や、そのような腺間を考虑し なかったがために生じたと想像されるような計算值と測 定値の不一致は発見できなかった。したがって、通常は このような部材間の隙間の影響は小さいと考えてよいる のと思われる。

3) 材料物性值の非一様性と非定常性について

前節で述べたように本検証において最大のポイントに なっているのがセメント系材料の物性值であるが、これ については既述の通り次の課題とし本論文では性急な結 論を避けたい。一方、非セメント系材料（本試験では木 質系材料と称してかまわないと思われる。）においては ハイグロスコピック領域という条件が付くが、物性值の 非一様性や非定常性に起因すると思われる計算値之実測 値の明膫な不一致は発見されなかった。したがって、軸 組部材等はともかく湿っていない木質系の面材について は物性値に対するこのような問題をそれほど危惧しなく てむよいものと思われる。

4) 初期含水率の設定方法

工場生産の材料といえどもD壁体のAＬＣのように初 期含水率が異常に高い材料が実際に使用されていること が分かり、初期結露の有無を検討する際にはこのような 初期含水率が重要であることが認識された。しかしなが ら、本試験の結果だけでもってこのような初期含水率の 
一般的な設定方法を提示することは到底無理であり、今 後さらに類似のデータを蓄積していく必要があることが 分かった。さらに、当然のことではあるが、このように 高含水率で提供される材料においては特に高含水率域に おける物性值が重要になるので、3）にも関連するが高 含水率域における物性值の正確な測定と扱い方が一層重 要になる。

このように、今回の検証では、木質系材料に対しては 八イグロスコピック領域という条件が付くが含水率や温 湿度の計算值と测定值は比較的よく一致することが確認 された。ただし、B壁体の防湿層の小孔のような特異な 例の場合には、1 次元計算であるが故に結露を正確に計 算することができなかった。一方、セメント系の物質を 含む材料においては、特に含水率について計算值と実剆 値との間にかなり明瞭な不一致が見られた。この原因と しては、測定された物性值の精度が悪かったことや計算 における物性值の扱い方が適当でなかったことなどが考 えられる。しかし、現段階では原因究明のための十分な 検討を行っていないので、本稿では原因を特定すること は避け、原因については次の課題として稿を改めて報告 することにしたい。

今回の試験に用いられた吸放湿性のある材料はA L C、 合板等の高々 6 種類である。勿論、これだけの材料で構 成される壁体や一種類の温湿度条件だけでは十分な検証 とは言い切れない。しかし、上記のような示唆に富む結 果と次の課題と考えられる問題点が明確になり、冒頭で 述べた研究目的をほぼ達成することができたと思われる。

\section{謝 辞}

本研究における試験は（財）日本建築センターに設置 された大規模木造建築技術研究会において実施されたす のである。当研究会に関与された各位には深く感謝した い。また、多くの助言を提供された松本衛教授（神戸大） をはじめとして、測定面で多大な協力を惜しまなかった 大沢元毅氏（建研）、瀬戸裕直氏（建研）、清水則夫氏 （ＢＬ）の諸兄には、記して最大の謝意を表したい。

\section{参考文献}

1) Matsumoto, M. Simultaneous Heat and Transfer in Porous Wall and Analysis of Internal Condensation, Energy Conservation in Heating, Cooling and Ventilating Buildings, Volume 1, pp. 45 58, 1978.

2) Hatsumoto, M. : Internal Condensation and Re-Evaporation Process of Moisture in a Foam Concrete. Proc. the VI th All-Union Heat and Mass Transfer Conf., Minsk, Volume 7,pp. 39〜45,1980.

3)松本衙、松下敬幸 : ハイグロスコビックの領域での気泡コンクリートの吸放湿性状

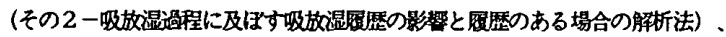
日本建築学会詥女報告集 第306号, pp65～71, 昭和56年8月.

4) 松本衙: 新建究大学 10 環境物理、影国社、1984

5)大規模木造建築技術研究報告害 №.3 棈法分科会、建設省建然研究所、（社）建策 采協会、（財）日本建管センター、平成2年8月.

6)建設省棇合技術開発プロジェクト 新木造建築技術の開発 報告書 No. 63-3 居住性 耐久性分科会、建設省建究研究所、平成元年3月.

7)建築学便臨 計画、丸普、1980。

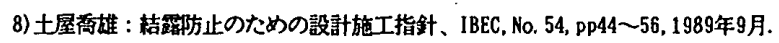
9) Iwasaki, M. and Tada S. :Carbonation of Aerated Concrete, Proc. Int. Symp. Cement \& Concrete, Bei jing, Vol. 3, pp. 343 356, 1985.

(1993 年 9 月 9 日原稿受理, 1994 年 1 月 14 日採用决定) 